\title{
Hatching mode and latitude in marine gastropods: revisiting Thorson's paradigm in the southern hemisphere
}

Received: 23 May 2000 / Accepted: 13 October 2000

\begin{abstract}
For much of the last century the developmental mode of marine invertebrates, particularly of prosobranch gastropods, has been thought to reflect a latitudinal pattern known as Thorson's rule; the proportion of species with pelagic larvae decreases with increase in latitude. Although the predictions of this rule have been criticized recently, its validity along latitudinal transects in the world ocean still remains poorly tested. In the present work, we compare the frequency of occurrence of contrasting prosobranch hatching modes (pelagic versus benthic development) along two latitudinal gradients of the subequatorial coastline of South America: the southeast Pacific and the southwest Atlantic. The results are clearly contrasting. While the pattern observed along the Pacific (Chilean) coast fits the predictions of Thorson's rule very well, benthic development predominates all along the Atlantic coast, even at subtropical latitudes. This difference in observed patterns is attributable to the different compositions of the gastropod assemblages on each side of the South American continent, which are determined, in turn, by differences in the ecological conditions on the two sides of the continent. The scarcity of pelagic development among the Atlantic prosobranch gastropods reflects the near-continuous soft-bottom habitat there, and the consequent prevalence of predaceous, soft-bottom taxa that had acquired in their evolution more evolved, nonpelagic patterns of development. In contrast, the Pacific coast is much more heterogeneous, with a diverse mix-
\end{abstract}

Communicated by O. Kinne, Oldendorf/Luhe

C. S. Gallardo $(\square)$

Instituto de Zoología E.F.Kilian,

Universidad Austral de Chile,

Casilla 567, Valdivia, Chile

e-mail: cgallard@uach.cl

P. E. Penchaszadeh

Facultad de Ciencias Exactas y Naturales,

Universidad de Buenos Aires, MACN-CONICET,

Avenida A. Gallardo 470, 1405 Buenos Aires, Argentina ture of benthic habitats, including rocky substrates that, in part, support grazing taxa. Our results indicate that two factors are important for Thorson's rule to be valid. First, the habitat needs to include rocky substrates, as soft-bottom habitats appear to favour non-pelagic development. Second, a diverse assemblage of taxa need to be compared to avoid the problem of phyletic constraints, which could limit the evolution of different developmental modes.

\section{Introduction}

The so-called Thorson's rule proposes that most species of marine invertebrates in high latitudes have direct development, omitting the larval planktotrophic phase, and the frequency of species with pelagic larvae (basically planktotrophic) increases gradually towards lower latitudes until they are predominant in tropical marine environments (Mileikovsky 1971). This view was promoted by Thorson $(1946,1950)$ and widely accepted for many years. Nevertheless, there have been exceptions to the pattern. For example, some groups, such as nudibranchs and ascoglossans, have a high incidence of direct development in the tropics (Clark and Goetzfried 1978). Moreover, recent work in the Antarctic has shown that many polar species have pelagic larvae (Pearse et al. 1991; Clarke 1992), particularly bivalve molluscs (Hain and Arnaud 1992) and echinoderms (Pearse et al. 1991; Pearse 1994).

On the other hand, Thorson's rule does appear to hold well with gastropods (Picken 1979, 1980; Pearse et al. 1991; Clarke 1992). Indeed, the pattern was based mainly on work with prosobranch gastropods, considered by Thorson (1950) as the barometer of the ecological conditions in the sea. However, most of the data on these gastropods were obtained in waters of the northern hemisphere (northeast Atlantic Ocean, Mediterranean Sea, Persian Gulf) (Thorson 1936, 1946, 1950; Mileikovsky 1971), while corroborative data from the southern hemisphere have been limited to antarctic and 
subantarctic waters (Picken 1980; Hain and Arnaud 1992). If latitude has such a general effect on the developmental mode of prosobranch gastropods, the phenomenon should be observed across temperate latitudes in both hemispheres of the planet.

In this paper, we present an analysis of the developmental mode of prosobranch gastropods (today included in the non-heterobranch clades) along the Pacific and Atlantic coasts of the southern cone of South America. We show that the latitudinal pattern is not the same on the two sides of the continent. Instead, Thorson's rule is followed on the Pacific coast, whereas non-pelagic development predominates all along the Atlantic coast. These different patterns appear to reflect differences in ecological conditions on the two coasts and may also indicate the possible importance of phyletic constraints in determining the developmental mode in different species. Following recent new schemes of classification proposed for prosobranch gastropods, we use here the term "non-heterobranch" gastropods to encompass patellogastropods, vetigastropods and caenogastropods clades defined by Ponder and Lindberg (1997).

\section{Materials and methods}

The frequency of developmental mode, that is, the indirect or pelagic development (PD) versus direct or non-pelagic development
(NPD) in relation to latitude, was analysed for the Pacific coast (Chile) and the Atlantic coast (southern Brazil, Uruguay, Argentina,) extending from $20^{\circ} \mathrm{S}$ to the Antarctic. For the Pacific coast, 32 species of non-heterobranch gastropods belonging to 14 families were studied (Table 1), while on the Atlantic coast, 29 species of 9 families were analysed (Table 2). Hatching mode and geographical distribution of the species were determined based on the works of Dell (1971), Cañete and Ambler (1992), Brown and Olivares (1996), Gallardo (1977a, b, 1979a, b, and unpublished data), Gallardo and González (1994) for gastropods of the South American Pacific. For the Atlantic species, the works of Arnaud (1978), Arnaud and Van Mol (1979), Borzone (1995), De Mahieu et al. (1974), Pastorino and Penchaszadeh (1998), Pastorino and Penchaszadeh (1999), Penchaszadeh (1971a, b, 1973, 1976); Penchaszadeh et al. (1999), Penchaszadeh and De Mahieu $(1975,1976)$ and unpublished data were reviewed.

With these data, the frequency of species with either developmental mode (PD or NPD) were calculated along a hypothetical latitudinal transect, recording this frequency for each 5 degrees of latitude for the Pacific and the Atlantic coasts of South America. For the antarctic-subantarctic area, the data provided on prosobranch gastropods by Picken (1979) were used. The information obtained was compared to the data reported by Thorson (1950) for prosobranchs of the northern hemisphere. The locations reported by Thorson were transformed to approximate latitude values.

\section{Results}

The results of this comparison for both hemispheres are shown in Tables 3 and 4 and graphically presented in

Table 1 Prosobranchs (non-heterobranch gastropods) of the Pacific (Chilean) coast; geographical distribution in Chile and hatching mode ( $P D$ indirect or pelagic development; $N P D$ direct or non-pelagic development)

\begin{tabular}{|c|c|c|c|c|}
\hline Family & Species & Distribution & Latitude & Hatching mode \\
\hline Acmaeidae & Nacella clypeater (Lesson, 1831) & Arica toValdivia & $18-40^{\circ} \mathrm{S}$ & PD \\
\hline Patellidae & N. magellanica (Gmelin, 1791) & Chiloé to Tierra del Fuego & $42-55^{\circ} \mathrm{S}$ & PD \\
\hline Trochidae & Tegula atra (Lesson, 1830) & Arica to Magellan Strait & $18-54^{\circ} \mathrm{S}$ & PD \\
\hline Turbinidae & Prisogaster niger (Wood, 1828) & Arica to Magellan Strait & $18-54^{\circ} \mathrm{S}$ & PD \\
\hline \multirow[t]{2}{*}{ Littorinidae } & Littorina peruviana (Lamarck, 1822) & Arica to Valdivia & $18-40^{\circ} \mathrm{S}$ & PD \\
\hline & L. araucana D'Orbigny, 1840 & Arica to Chiloé & $18-43^{\circ} \mathrm{S}$ & PD \\
\hline Turritelidae & Turritella cingulata Sowerby, 1825 & Arica to Chiloé & $18-43^{\circ} \mathrm{S}$ & PD \\
\hline \multirow[t]{3}{*}{ Ranellidae } & Priene rude (Broderip, 1833) & Arica to Magellan Strait & $18-54^{\circ} \mathrm{S}$ & PD \\
\hline & Argobuccinum ranelliformis (King, 1832) & Caldera to Magellan Strait & $27-54^{\circ} \mathrm{S}$ & PD \\
\hline & Fusitriton magellanicus (Röding, 1798) & Los Vilos to Magellan Strait & $31-54^{\circ} \mathrm{S}$ & PD \\
\hline \multirow[t]{6}{*}{ Calyptraeidae } & Calyptraea trochiformis (Gmelin, 1790) & Arica to Valparaiso & $18-33^{\circ} \mathrm{S}$ & NPD \\
\hline & Crepidula fecunda Gallardo, 1979 & Tumbes to Quitralco Fjord & $36-45^{\circ} \mathrm{S}$ & PD \\
\hline & C. dilatata Lamarck, 1822 & San Marcos Bay to Tierra del Fuego & $21-55^{\circ} \mathrm{S}$ & NPD \\
\hline & C. philippiana Gallardo, 1977 & Mehuín to Port Refugio & $39-46^{\circ} \mathrm{S}$ & NPD \\
\hline & C. coquimbensis Brown \& Olivares, 1996 & La Herradura (Coquimbo) & $29-30^{\circ} \mathrm{S}$ & NPD \\
\hline & Crucibulum lignarium (Broderip, 1834) & Tomé to Quitralco Fjord & $36-46^{\circ} \mathrm{S}$ & PD \\
\hline Naticidae & Sinum cymba (Menke, 1828) & Arica to Coquimbo & $18-30^{\circ} \mathrm{S}$ & PD \\
\hline \multirow[t]{2}{*}{ Nassaridae } & Nassarius gayi (Kiener, 1835) & Arica to Magellan Strait & $18-54^{\circ} \mathrm{S}$ & PD \\
\hline & N. dentifer (Powys, 1835) & Arica to Chiloé & $18-43^{\circ} \mathrm{S}$ & PD \\
\hline Collumbellidae & Mitrella unifasciata (Sowerby, 1832) & Arica to Magellan Strait & $18-54^{\circ} \mathrm{S}$ & PD \\
\hline \multirow[t]{9}{*}{ Muricidae } & Thais haemastoma (Linneo, 1767) & Arica to Iquique & $18-20^{\circ} \mathrm{S}$ & PD \\
\hline & T. chocolata (Duclos, 1832) & Arica to Coquimbo & $18-30^{\circ} \mathrm{S}$ & PD \\
\hline & Concholepas concholepas (Bruguière, 1789) & Arica to Tierra del Fuego & $18-55^{\circ} \mathrm{S}$ & PD \\
\hline & Xanthochorus cassidiformis (Blainville, 1832) & Arica to Moraleda Channel & $18-45^{\circ} \mathrm{S}$ & PD \\
\hline & Crassilabrum crassilabrum (Sowerby, 1834) & Arica to Valdivia & $18-40^{\circ} \mathrm{S}$ & PD \\
\hline & Chorus giganteus (Lesson, 1829) & Papudo to Calbuco & $32-41^{\circ} \mathrm{S}$ & PD \\
\hline & Nucella crassilabrum (Lamarck, 1816) & Caldera to Tierra del Fuego & $27-55^{\circ} \mathrm{S}$ & NPD \\
\hline & Trophon geversianus (Pallas, 1769) & Magellan Strait and Tierra del Fuego & $50-55^{\circ} \mathrm{S}$ & NPD \\
\hline & T. plicatus (Lightfoot, 1786) & Chile Austral and Tierra del Fuego & $46-55^{\circ} \mathrm{S}$ & NPD \\
\hline & Pareuthria plumbea (Philippi, 1844) & Constitución to Tierra del Fuego & $35-55^{\circ} \mathrm{S}$ & NPD \\
\hline \multirow[t]{2}{*}{ Volutidae } & Adelomelon ancilla (Lightfoot, 1786) & Chiloé to Tierra del Fuego & $42-55^{\circ} \mathrm{S}$ & NPD \\
\hline & Odontocymbiola magellanica (Chemnitz, 1788) & Chiloé to Tierra del Fuego & $42-55^{\circ} \mathrm{S}$ & NPD \\
\hline
\end{tabular}


Table 2 South American prosobranchs (non-heterobranch gastropods) of the subequatorial Atlantic coast; geographical distribution and hatching modes ( $P D$ indirect or pelagic development; $N P D$ direct or non-pelagic development)

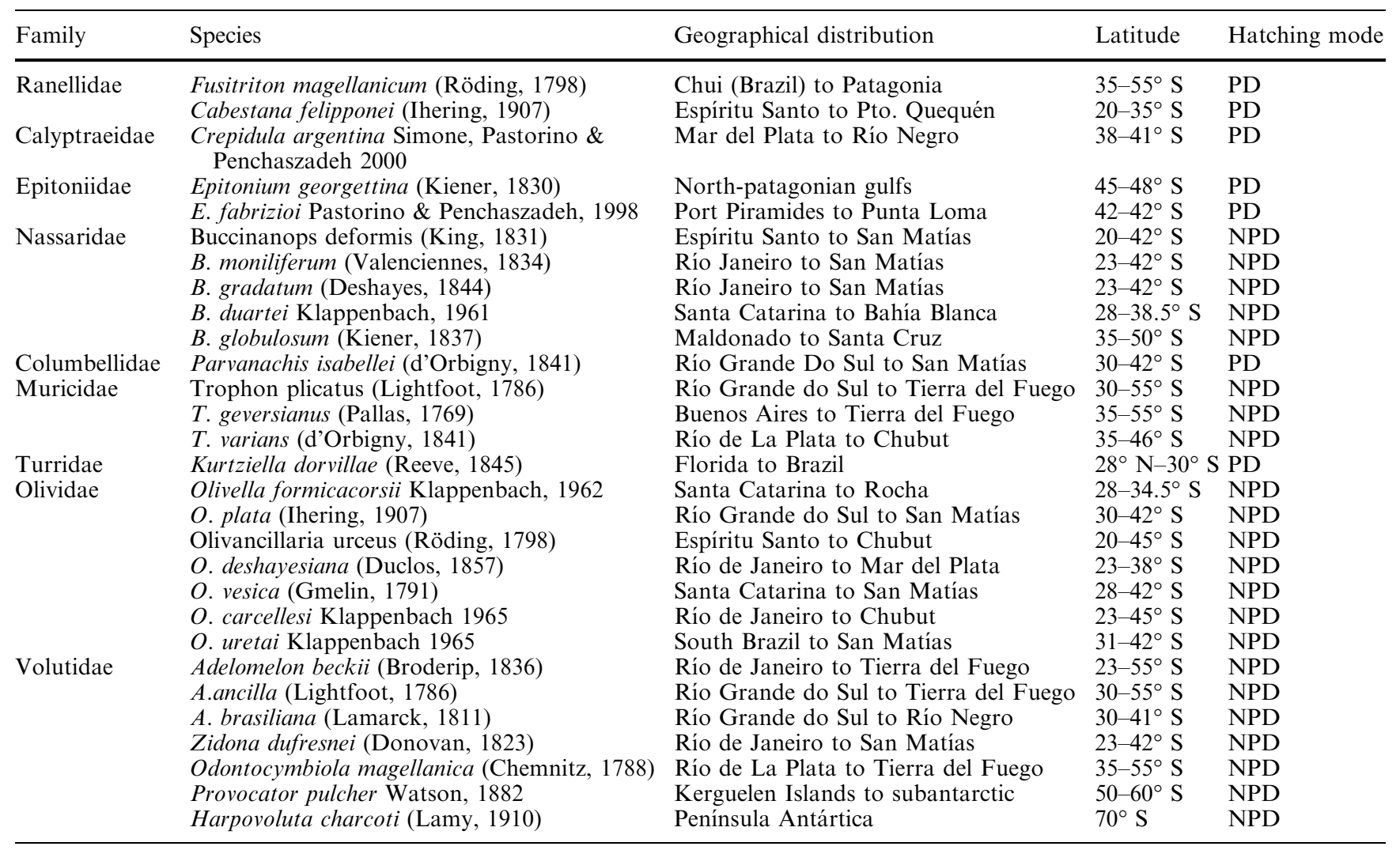

Table 3 Proportion of prosobranch (non-heterobranch) gastropods species with each mode of development on the Pacific coast (Chile). [PD indirect or pelagic development; $N P D$ direct or non-pelagic development; $S A-A^{*}$ subantarctic and antarctic areas according to Picken (1979)])

\begin{tabular}{llllr}
\hline $\begin{array}{l}\text { Observed } \\
\text { latitude }\end{array}$ & $\begin{array}{l}\text { Number of } \\
\text { species with PD }\end{array}$ & $\%$ & $\begin{array}{l}\text { Number of } \\
\text { species with NPD }\end{array}$ & $\%$ \\
\hline $20^{\circ} \mathrm{S}$ & 17 & 94 & 1 & 6 \\
$25^{\circ} \mathrm{S}$ & 16 & 89 & 2 & 11 \\
$30^{\circ} \mathrm{S}$ & 16 & 80 & 4 & 20 \\
$35^{\circ} \mathrm{S}$ & 16 & 84 & 3 & 16 \\
$40^{\circ} \mathrm{S}$ & 18 & 82 & 4 & 18 \\
$45^{\circ} \mathrm{S}$ & 12 & 67 & 6 & 33 \\
$50^{\circ} \mathrm{S}$ & 9 & 56 & 7 & 78 \\
$55^{\circ} \mathrm{S}$ & 2 & 22 & 7 & 82 \\
$\mathrm{SA}^{\circ}$-A & 3 & 18 & 14 & \\
\hline
\end{tabular}

Fig. 1. Non-heterobranch marine gastropods on the Pacific coast (Table 3; Fig. 1A) follow the latitudinal pattern outlined by Thorson's rule for the northern hemisphere (Fig. 1C); there is a gradual replacement of species with indirect development by species with direct development as latitude increases towards the southern polar region.

However, the predictions based on this paradigm do not hold in the case of non-heterobranch gastropods examined from the Atlantic coast (Table 4; Fig. 1B). Here, the latitudinal transect shows that the proportion of species with indirect development remains below $20 \%$ throughout most of the latitudinal gradient; even at the lowest latitude, at the edge of the tropics, the proportion of species with pelagic larvae is only $33 \%$.

\section{Discussion}

The present work indicates that patterns of developmental mode in prosobranch gastropods reflect more complex relationships than simply latitudinal dependency. Thorson's scheme is basically true as far as its prediction for polar environments is concerned, where a majority of non-heterobranch gastropods have direct development in both hemispheres (Thorson 1950; Mileikovsky 1971; Picken 1979, 1980; Clarke 1992; Hain and Arnaud 1992). On the other hand, when analysing the data shown in the present work along the southern South American coast, no general coherent latitudinal gradient tendency as predicted by the model is found. In contrast, the latitudinal gradient in developmental mode seen on the Pacific coast is exceptionally clear and among the most marked seen anywhere in the world. No such pattern is seen on the Atlantic coast of South America, however. The contrast in the observed differences between the Pacific and the Atlantic coasts demonstrates the predictive limitations of this model.

There are at least two factors that distinguish both assemblages of South American gastropods and that 

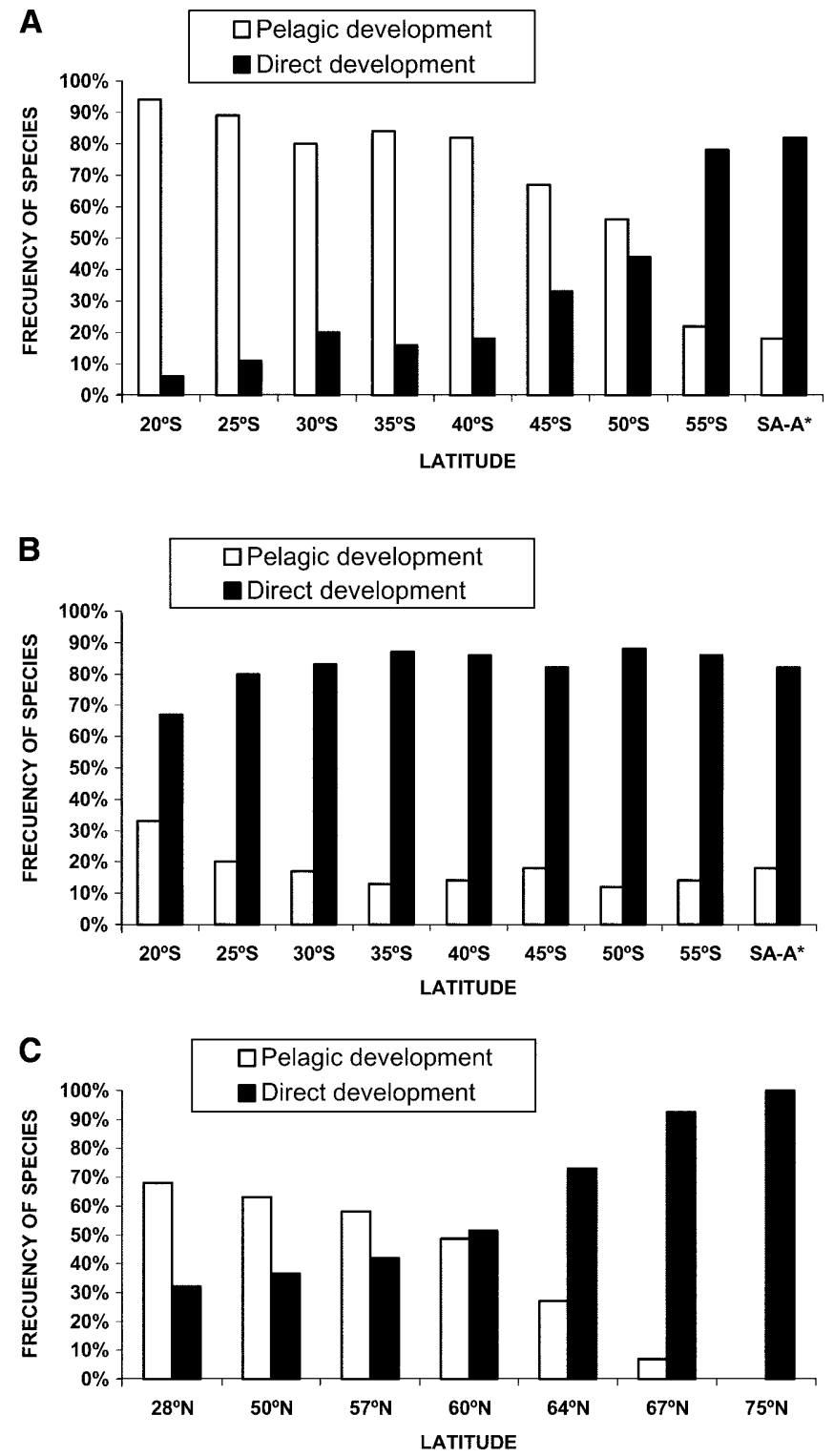

Fig. 1 Frequency of prosobranch (non-heterobranch) gastropods with each mode of development along a latitudinal gradient in the Pacific (Chilean) (A) and the Atlantic (B) subequatorial coast of South America, including data of Picken (1979) for subantarctic and antarctic area $\left(\mathrm{S} A-A^{*}\right)$. C Frequency of prosobranch gastropods with each mode of development along a latitudinal gradient from the Canary Islands to Greenland in the northern hemisphere (modified from Thorson 1950)

could lead to the differences in the developmental modes we observed: (1) different species composition; and (2) differences in geomorphology and types of bottom substrate between the two main coasts of the South American continent.

Point 1 relates to the evolutionary history of developmental pattern among higher taxa and the possibility that an irreversible change had occurred in some taxa, especially towards non-pelagic development and eventually with the brooding of the young. Phyletic restrictions (or constraints) shared by the members of such
Table 4 Proportion of South American prosobranch (non-heterobranch) gastropod species with each mode of development on the Atlantic subequatorial coast $[P D$ indirect or pelagic development; $N P D$ direct or non-pelagic development; $S A-A^{*}$ subantarctic and antarctic areas according to Picken (1979)])

\begin{tabular}{lllll}
\hline $\begin{array}{l}\text { Observed } \\
\text { latitude }\end{array}$ & $\begin{array}{l}\text { Number of } \\
\text { species with PD }\end{array}$ & $\%$ & $\begin{array}{l}\text { Number of } \\
\text { species with NPD }\end{array}$ & $\%$ \\
\hline $20^{\circ} \mathrm{S}$ & 1 & 33 & 2 & 67 \\
$25^{\circ} \mathrm{S}$ & 2 & 20 & 8 & 80 \\
$30^{\circ} \mathrm{S}$ & 3 & 17 & 15 & 83 \\
$35^{\circ} \mathrm{S}$ & 3 & 13 & 20 & 87 \\
$40^{\circ} \mathrm{S}$ & 3 & 14 & 18 & 86 \\
$45^{\circ} \mathrm{S}$ & 2 & 18 & 9 & 82 \\
$50^{\circ} \mathrm{S}$ & 1 & 12 & 7 & 86 \\
$55^{\circ} \mathrm{S}$ & 1 & 14 & 6 & 82 \\
$\mathrm{SA}^{*}$ & 3 & 18 & 14 & \\
\hline
\end{tabular}

taxa would later limit evolutionary change of embryonic and larval development. As a general rule, patellogastropods and vetigastropods (including here limpets, Fissurelloidea, Trochoidea) develop through a pelagic larva, while caenogastropods show both pelagic and non-pelagic developmental modes, with considerable diversity in the families Calyptraeidae (herbivores, filter feeders) and Muricidae (carnivores). Direct (non-pelagic) development is found in all species in the family Volutidae and all species in the genera Trophon and Nucella (within the Muricidae). The Pacific coast (Chile) shows a diversity of prosobranch (non-heterobranch) clades, including patellogastropods, vetigastropods, and a variety of non-neogastropod caenogastropods (sensu Ponder and Lindberg 1997), with the latitudinal gradient in developmental mode being clearly evident. On the other hand, the Atlantic coast shows a clear predominance of clades with non-pelagic larvae, mostly represented by Buccinanops, Trophon and members of the family Volutidae. If Thorson's rule has a general validity in the ocean, independent of the predominant gastropod taxa, one would expect that most species with non-pelagic development would be equally excluded from subtropical and temperate latitudes. The nonfulfilment of this prediction along the South American Atlantic coast suggests that phylogenetic constraints linked to the particular history of a group have an important role in determining the developmental modes of marine gastropods in any one area, rather than latitude by itself. For polar waters of the North Pacific, Lindberg (1998) discusses possible scenarios for the evolution of brooding (non-pelagic development) among marine invertebrates, using in part evidence from the Tertiary fossil record. According to this author, clade-specific patterns suggest different causes for different taxa; the dominance of brooders in boreal and arctic Pacific waters appears to have resulted from endemic radiations in some clades and from species selection in others. Species selection on variability in life history strategies (brood or broadcaster taxa) as expressed in different lineages could also have produced the pattern seen in the polar regions. 
Besides the case of nudibranch and ascoglossan gastropods displaying a high incidence of non-pelagic development in the tropics, there are other studies showing that Thorson's rule did not apply to all marine gastropods, and that developmental mode is in some way also related to the taxon's particular evolutionary history. For example, Radwin and Chamberlain (1973) reported that neogastropods, well represented in tropical waters, have predominantly non-planktonic development at all latitudes. Coinciding with our opinion, these authors suggest that the mode of development in these clades tends to follow phyletic lines regardless of latitude or climatic conditions.

Regarding point 2, undoubtedly the physical history of a coast and its waters (including its geomorphology), as well as the faunistic composition, have an influence on the evolutionary development of the established gastropod communities. The Pacific South American coast is basically rocky (coastal mountain chain, the Cordillera de la Costa) with an abundant and rich substrate for the development of herbivores feeding on a great diversity of algae, but nevertheless includes environmental diversity (sandy-beach bays with channels and archipelagos towards the south). On the other hand, the Atlantic coast is an extensive platform with basically sandy bottoms. The guild of the herbivore gastropods (patello-, veti- and low caenogastropod clades of hard substrates) is very limited there, with a prevalence of carnivorous families that find an abundant prey fauna, basically sandy-bottom bivalve molluscs. This difference in geomorphologic history between the two coasts has contributed to determining the different faunistic compositions of gastropods and seems to be another factor determining the observed modes of development. The physical characteristics of the water (particularly thermal regime and systems of coastal circulation) could also be important, but we have no information on that. For instance, Knudsen (1950) attributed certain regional anomalies in the latitudinal gradient of the observed modes of development in the gastropods of the southwest coast of Africa to the cold Guinea Current.

From this study we can conclude that, in non-polar waters, latitude does not always determine a gradient of developmental modes among non-heterobranch gastropods. It seems that the predicted scheme would be fulfilled where there is enough environmental variation to support the wide phyletic diversity of the group (as is the case on the coast of Chile). The apparent uniformity of the sandy bottom on the Atlantic side seems to have excluded the possibility of success of taxa with pelagic larva (which are successful in communities on rocky substrates). The absence of these taxa, which are competitively superior in larval dispersion and colonization, seems to have allowed the establishment in the South American Atlantic of species with direct development even in very low latitudes, normally inhabited on other coasts by species with pelagic development. The type of bottom associated with it would also play an important role. Such a relationship seems particularly important in the case of neogastropods, a group highly inclined to evolve complex reproductive stragegies involving direct development. In this sense, Spight (1977) compared the latitudinal gradient of developmental modes of muricid gastropods in relation to the type of bottom substrate they inhabited. He found that the type of development changes more pronouncedly between muricids of rocky coasts than in the whole group of prosobranchs. On rocky coasts, all the high-latitude species have direct development and all the tropical species have planktonic larvae. Also, species with a given mode of development are replaced by ecological equivalents of the other mode through the latitudinal gradient. In turn, the same does not apply to the sandy-bottom muricids, and species with direct development prevail at several latitudes. An intermediate type of non-feeding veliconch larva that remains near the bottom may also exist, as in the Chilean sandy-bottom muricid Chorus giganteus (sensu Gallardo 1981). Spight (1977) suggests that the low number of tropical species with direct development, as reported in Thorson's and Mileikovsky's studies, could be biased, given that many of the species studied up to that time were basically from rocky substrates. If other habitats were studied, probably a much higher frequency of species with direct development would be observed in low latitudes. The conclusions reported by Spight (1977) in muricids are mostly in accordance with our general observations of other non-heterobranch families, if we consider the prevailing type of substrates between the two South American coasts compared herein, and invite future studies in this direction.

Acknowledgements We would like to thank Dr. John S. Pearse (Institute of Marine Sciences, Santa Cruz, Calif.), Dr. Richard Strathmann (Friday Harbor Laboratory Wash.) and Dr. Roberto Cipriani (University of Chicago) for reviewing earlier drafts of the manuscript. The present study was partially supported by the Volkswagen Foundation Project I 96-01, by pict (98-01-04321) (Argentina) and by a contest grant of the Foundations ANTORCHAS (Argentina), VITAE (Brazil) and ANDES (Chile). Additional support from Project DID-UACH (S 199951) is also acknowledged. Rodrigo Merino gave valuable assistance in the preparation of the figures. We thank also an anonymous reviewer for valuable editorial comments which have improved the manuscript.

\section{References}

Arnaud PM (1978) Observations écologiques et biologiques sur le Volutidae antarctique Harpovoluta charcoti (Lamy, 1910) (Gastropoda: Prosobranchia). Haliotis 7: 44-46

Arnaud PM, Van Mol J-J (1979) Anatomy, ecology and distribution of the Volutidae and Volutomitridae (Gastropoda: Prosobranchia) of the Southern Indian Ocean. Veliger 22(1): 19-31

Borzone CA (1995) Ovicápsulas de prosobranquios (Mollusca: Gastropoda) de una playa arenosa expuesta del sur del Brasil. Ihergingia Ser Zool (Porto Alegre) 79: 47-58

Brown DI, Olivares CA (1996) A new species of Crepidula (Mollusca: Mesogastropoda: Calyptraeidae) from Chile: additional characters for the identification of eastern Pacific planar Crepidula group. J Nat Hist 30: 1443-1458

Cañete JI, Ambler RP (1992) Desarrollo intracapsular del gastrópodo comestible Calyptraea (Trochita) trochiformis (Born 1778) en Chile. Rev Chil Hist Nat 65: 256-266 
Clarke A (1992) Reproduction in the cold: Thorson revisited. Invertebr Reprod Dev 22: 175-184

Clark KB, Goetzfried A (1978) Zoogeographic influences on development patterns of North Atlantic Ascoglossa and Nudibranchia, with a discussion of factors affecting egg size and number. J Molluscan Stud 44: 283-294

Dell RK (1971) The marine Molluscs of the Royal Society Expedition to Southern Chile. Rec Dom Mus Wellington 7: 155-233

De Mahieu G, Penchaszadeh PE, Casal A (1974) Algunos aspectos de las variaciones de proteínas y aminoácidos libres totales del líquido intracapsular en relación al desarrollo embrionario en Adelomelon brasiliana (Lamarck, 1811) (Gastropoda, Prosobranchiata, Volutidae). Cah Biol Mar (Paris) XV(228): 215-227

Gallardo CS (1977a) Two modes of development in the morphospecies Crepidula dilatata (Gastropoda, Calyptraeidae) from Southern Chile. Mar Biol 39: 241-251

Gallardo CS (1977b) Crepidula philippiana n.sp., nuevo gastrópodo Calyptraeidae de Chile con especial referencia al patrón de desarrollo. Stud Neotrop Fauna Environ 12: 177-185

Gallardo CS (1979a) Especies gemelas del género Crepidula en la costa de Chile; una redescripción de $C$. dilatata Lamarck y descripción de $C$. fecunda n.sp. Stud Neotrop Fauna Environ 14: $215-226$

Gallardo CS (1979b) Developmental pattern and adaptations for reproduction in Nucella crassilabrum and other muricaeans gastropods. Biol Bull (Woods Hole) 157: 453-463

Gallardo CS (1981) Posturas y estadio de eclosión del gastrópodo Muricidae Chorus giganteus (Lesson, 1829). Stud Neotrop Fauna Environ 16: 35-44

Gallardo CS, González KA (1994) Ovipostura y desarrollo intracapsular de Xanthochorus cassidiformis (Blainville, 1832) (Gastropoda, Muricidae) de la costa sur de Chile. Gayana Zool 58: 79-90

Hain S, Arnaud PM (1992) Notes on the reproduction of highAntarctic molluscs from the Weddell Sea. Polar Biol 12: 303312

Knudsen J (1950) Egg capsules and development of some marine prosobranchs from tropical West Africa. Atl Rep 1: 85-130

Lindberg DR (1998) On the evolution of parental care in marine invertebrates: is Thorson's Rule the result of species selection on variability? Proceedings of the 8th International Congress on Invertebrate Reproduction and Development, Amsterdam. pp 82

Mileikovsky SA (1971) Types of larval development in marine bottom invertebrates, their distribution and ecological significance: a re-evaluation. Mar Biol 10: 193-213

Pastorino G, Penchaszadeh PE (1998) Epitonium fabrizioi (Gastropoda: Epitoniidae), a new species from Patagonia, Argentina. Nautilus 112: 63-68

Pastorino G, Penchaszadeh PE (1999) On the egg capsules of Epitonium georgettinum (Kiener, 1839) (Gastropoda: Epitoniidae) from Patagonian shallow waters. Veliger 42(2): 205-207
Pearse JS (1994) Cold-water echinoderms break Orton's and Thorson's "rules". In: Young CM, Eckelbarger K (eds) Invertebrate reproduction, larval biology and recruitment in deep-sea benthos. Columbia University Press, New York, p 26-43

Pearse JS, McClintock JB, Bosch I (1991) Reproduction of Antarctic benthic marine invertebrates: tempos, modes and timing. Am Zool 31: 65-80

Penchaszadeh PE (1971a) Observaciones sobre la reproducción y ecología de Dorsanum moniliferum (Valenciennes, 1834) (Gastropoda, Buccinidae) en la región de Mar del Plata. Neotropica 17(53): 49-54

Penchaszadeh PE (1971b) Aspectos de la embriogénesis de algunos gasterópodos del género Buccinanops d'Orbigny, 1841 (Gastropoda, Buccinidae, Prosobranchiata). Physis 81: 475-483

Penchaszadeh PE (1973) Nuevas observaciones sobre la reproducción de Buccinanops gradatum (Des, 1844) (Gastropoda, Prosobranchia, Dorsaninae). Physis A 32(84): 15-18

Penchaszadeh PE (1976) Reproducción de gasterópodos prosobranquios del Atlántico Suroccidental. El género Trophon. Physis A 35(90): 69-76

Penchaszadeh PE, De Mahieu G (1975) Reproducción de gasterópodos prosobranquios del Atlántico Suroccidental. Cymatiidae. Physis A 34(89): 445-452

Penchaszadeh PE, De Mahieu G (1976) Reproducción de gasterópodos prosobranquios del Atlántico Suroccidental. Volutidae. Physis A 35(91): 145-153

Penchaszadeh PE, Miloslavich P, Lasta M, Costa PMS (1999) Spawn in members of the genus Adelomelon (Caenogastropoda: Volutidae) from the Atlantic coast of South America. Nautilus 113(2): 73-83

Picken GB (1979) Non-pelagic reproduction of some antarctic prosobranch gastropods from Signy Island, South Orkney Islands. Malacologia 19(1): 109-128

Picken GB (1980) Reproductive adaptations of Antarctic benthic invertebrates. Biol J Linn Soc 13: 67-75

Ponder WF, Lindberg DR (1997) Towards a phylogeny of gastropod molluscs: an analysis using morphological characters. Zool J Linn Soc 119: 83-265

Radwin GE, Chamberlin JL (1973) Patterns of larval development in stenoglossan gastropods. Trans San Diego Soc Nat Hist 17: 107-118

Spight TM (1977) Latitude, habitat and hatching type for muricacean gastropods. Nautilus 91: 67-71

Thorson G (1936) The larval development, growth and metabolism of Arctic marine bottom invertebrates compared with those of other seas. Medd Groenl 100: 1-155

Thorson G (1946) Reproduction and larval development of Danish marine bottom invertebrates, with special reference to the planktonic larvae in the Sound (Oresund). Medd Dan Fisk Havunders (Ser Plankton) 4: 1-529

Thorson G (1950) Reproductive and larval ecology of marine bottom invertebrates. Biol Rev 25: 1-45 